\title{
THE EFFECT OF MARKETING ON ORGANIC RICE CULTIVATION SUSTAINABILITY IN BOYOLALI REGENCY OF INDONESIA
}

\author{
Permatasari Putri*, Anantanyu Sapja, Dewi Widyatmani Sih \\ Master Program, Sebelas Maret University, Indonesia \\ *E-mail: putri.permatasari111@gmail.com
}

\begin{abstract}
This research was conducted from December 2016 to February 2017 in Boyolali Regency. The location was selected because Boyolali Regency was the one cultivating organic rice since 2009 until today and has successfully exported it to Belgium and Germany in 2013. The analysis technique employed in this study was a Multiple Linear Regression; the sample consisted of 86 farmers living in the Sub Districts having widest organic rice farmland: Sambi, Mojosongo, and Andong. The result of research showed that marketing affected directly the sustainability of organic rice cultivation significantly with t-test probability (Sign) value of 0,017 less than specified $\alpha$ of 0,05 . It indicated that organic rice product marketing, price, and market demand affected the sustainability of organic rice cultivation.
\end{abstract}

\section{KEY WORDS}

Marketing, sustainability, organic rice, farmers.

Indonesia is an agrarian state and development in agricultural field becomes its main priority in regional economic development. The development of agriculture is very important as the main food sector in Indonesia. It is because more than $55 \%$ of Indonesian populations work in agricultural sector and live in rural areas (Suprihono, 2003). The awareness of danger resulting from synthetic chemical use in farming makes organic farming interesting to both producers and consumers. Most consumers prefer health-safe and environment-friendly food material, thereby encouraging the increase in the demand for organic product. Indonesia has substantial potency, for example, many land resources have not be utilized to develop organic farming system, and technology has been available to support organic farming such as compost production, planting without land cultivation and natural pesticide.

Government has launched many policies in organic farming development, but the development of organic farming in Indonesia still runs very slowly. This condition is due to some constraints: market, understanding on organic product and certification process considered as hard by small farmers. Since the last two decades, the world market's demand for organic farming product begins to grow. However the growth of organic farming product is still low. The consumers of organic product are still limited to those who highly concerns with environment preservation and health. This phenomenon reveals limited domestic market that still becomes main constraint. The constraint often encountered is that many farmers have not been interested in organic farming. The reluctance results from unclear organic farming product market including the price obtained. Farmers' interest in practicing this organic farming will improve when domestic market can be grown.

Indonesia has large potency in developing organic farming, particularly organic rice. Several regencies in Central Java, on of which Boyolali Regency, start to pioneer the development of organic rice farming system. Organic rice farming develops rapidly in Boyolali Regency. Boyolali Regency is one of regencies in Central Java having the second widest organic land, 318,45 ha (AOI, 2015). Agricultural, Forestry and Plantation Service of Boyolali Regency reports farm rice productivity of 5,8 ton/ha in 2015 (BPS of Boyolali Regency 2016). This rice productivity can contribute to fulfilling the demand for high quality rice. However, it should be supported with marketing as well. Marketing process plays an important role in supporting the distribution of products to consumers. This research aimed to analyze the effect of marketing on the sustainability of organic rice cultivation in Boyolali Regency. 


\section{METHODS OF RESEARCH}

This research was taken place in Boyolali Regency because this regency has cultivated organic rice since 2009 until today. This study was an explanatory research, the one explaining causal relationship between variable through hypothesis testing (Effendi and Tukiran, 2014). Sampling technique employed was multistage cluster random sampling, classified by land width, village, and farmer group. Sub District sample was taken based on the one having widest land in organic rice cultivation, including Sambi, Mojosongo, and Andong Sub Districts. The sampling technique used was simple random sampling with lottery method. This research employed multiple linear regression analysis to test the correlation between variables and the sample of research consisted of 86 respondents.

Table 1 - Sub Districts, Villages and Farmer Groups becoming the sample

\begin{tabular}{lllllll}
\hline No. & Districts & Village & Farmer Group & Land Area (ha) & Members & Sample \\
\hline 1. & Sambi & Jatisari & Sido Mulyo & 22 & 56 & 8 \\
\hline & & Ngudi Rejeki & 20,1 & 74 & 11 \\
\hline & & Sido Tentrem & 11,0 & 68 & 10 \\
\hline & & Catur & Budi Rahayu & 18,03 & 76 & 12 \\
\hline & & Semono & Kismo Luhur & 8 & 11 & 2 \\
\hline 2. & Mojosongo & Metuk & Rukun Tani & 28,6 & 56 & 8 \\
\hline & & Dlingo & Pangudi Bogo & 24,87 & 97 & 15 \\
\hline & & Pangudi Raharjo & 16,46 & 55 & 8 \\
\hline 3. & Andong & Nduwet & Bina Lingkungan & 14,5 & 45 & 7 \\
\hline & & Sruwoh & Lestari Makmur & 13,5 & 33 & 5
\end{tabular}

Source: Primary Data (Questionnaire), 2017.

\section{RESULTS AND DISCUSSION}

The respondents of research were farmers managing organic rice cultivation in Sambi, Mojosongo, and Andong Sub Districts.

Table 2 - Characteristics of Respondents by Age

\begin{tabular}{llllll}
\hline Characteristisc of Respondents & Criteria & & Amount & Percentage (\%) \\
\hline Age (years) & Old & $:$ & $\leq 40$ years & 16 & 18,6 \\
& Young & $:$ & $41-49$ years & 34 & 39,5 \\
& Elderly & $:$ & $\geq 50$ years & 36 & 41,9 \\
\hline
\end{tabular}

Source: Primary Data (Questionnaire), 2017.

Table 2 shows that 16 respondents $(18,6 \%)$ are less than 40 years old, 34 respondents $(39,5 \%)$ are $41-49$ years old, and 36 respondents $(41,9 \%)$ are 50 years old. Most respondents have been elders, more than 50 years old. Kartasapoetra (1987), the farmers aged more than 50 years are usually fanatic with tradition and difficult to give understanding that can change their ways of thinking, working, and living.

An individual's education level will affect his/her attitude, perspective and ability of doing something. Mardikanto (1982) suggests that education will affect an individual's ways of thinking and mindset. The higher the education of an individual, the higher is the knowledge, attitude, and skill levels.

Table 3 - Characteristics of Respondent by Formal Education Level

\begin{tabular}{|c|c|c|c|c|}
\hline $\begin{array}{l}\text { Characteristisc of } \\
\text { Respondents }\end{array}$ & Criteria & & Amount & $\begin{array}{l}\text { Percentage } \\
(\%)\end{array}$ \\
\hline \multicolumn{5}{|l|}{ Formal Education } \\
\hline & Low & : Uneducated-Graduated from Elementary School & 41 & 47,7 \\
\hline & Medium & $\begin{array}{l}\text { Graduated Junior High School- Senior High } \\
\text { School }\end{array}$ & 36 & 41,9 \\
\hline & High & : Graduated Diploma-Bachelor & 9 & 10,5 \\
\hline
\end{tabular}

Source: Primary Data (Questionnaire), 2017. 
Table 3 shows that by formal education level, 41 respondents $(47,7 \%)$ are not graduated or graduated from Elementary School, 36 respondents $(41,9 \%)$ graduated from Junior and Senior High Schools and 9 respondents (10,5\%) graduated from Diploma until Bachelor. Thus, formal education level of respondent farmers is still low. Most farmers have been old, so that formal education did not get adequate attention.

Table 4 - Characteristics of Respondents by Non-Formal Education Level

\begin{tabular}{llllll}
\hline Characteristisc of Respondents & Criteria & Amount & & Percentage (\%) \\
\hline Extention Education & Low & $:$ & $0-1$ time & 7 & 8,1 \\
& Medium & $:$ & $2-3$ time & 62 & 72,1 \\
Training & High & $:$ & $\geq 4$ time & 17 & 19,8 \\
& Low & $:$ & $0-1$ time & 33 & 38,4 \\
& Medium & $:$ & $2-3$ time & 34 & 39,5 \\
& High & $:$ & $\geq 4$ time & 19 & 22,1 \\
\hline
\end{tabular}

Source: Primary Data (Questionnaire), 2017.

Table 4 shows that 7 respondents $(8,1 \%)$ attended $0-1$ time-extension activity in one planting season, 62 respondents attended 2-3-time extension (72,1\%) and 17 respondents $(19,8 \%)$ attended $\geq 4$-time extension. About 33 respondents $(38,4 \%)$ perform $0-1$ timepractice, 34 respondents $(39,5 \%)$ perform 2-3 time-practice and 19 respondents $(22,1 \%)$ perform $\geq 4$-time practice. Non-formal education level of farmers belongs to medium category in which they have ever attended extension and practice activities 2-3 times in one planting season. The farmers' activeness in attending extension and practice activity is very important because it is expected top bring about the change in knowledge, attitude, and skill.

Land mastery is a land width attempted by respondent farmers for organic rice farming activity.

Mardikanto (1994) suggests that farmers with narrow land, limited capital,, limited knowledge and skill often have poor spirit and less wish to go forward. The ownership status of land is the ownership status of land used for cultivating organic rice.

Table 5 - Characteristics of Respondents by Land Mastery

\begin{tabular}{llllll}
\hline Characteristisc of Respondents & Criteria & & & Amount & Percentage (\%) \\
\hline Land Mastery & Low & $:$ & $<0,25 \mathrm{Ha}$ & 13 & 15,1 \\
& Medium & $:$ & $0,25-0,49 \mathrm{Ha}$ & 65 & 75,6 \\
& High & $:$ & $0,50-0,99 \mathrm{Ha}$ & 8 & 9,3 \\
\hline Land Ownership Status & Low & $:$ & Peasants & 5 & 5,8 \\
& Medium & $:$ & Lessee & 21 & 24,4 \\
& High & $:$ & Own & 60 & 69,8 \\
\hline
\end{tabular}

Source: Primary Data (Questionnaire), 2017.

Table 5 shows that 13 respondents (15.1\%) have land mastery of less than $0,25 \mathrm{Ha}, 65$ respondents $(75,6 \%)$ have $0,25 \mathrm{Ha}-0,49 \mathrm{Ha}$ wide land and 8 respondents $(9,3 \%)$ have 0,50 $\mathrm{Ha}-0,99 \mathrm{Ha}$ wide land. Most respondents have land mastery of $0,25 \mathrm{Ha}-0,49 \mathrm{Ha}$, belonging to medium category. The farmers having farming land try to make innovation in some of their farming land, without being afraid of failure.

By the land ownership status, 5 respondents $(5,8 \%)$ are peasants, 21 respondents $(24,4 \%)$ are lessee, and 60 respondents $(69,8 \%)$ own their land. The land ownership status of most respondents belongs to high category, self-owned land, so that they have freedom in making decision in organic rice cultivation.

Marketing is any effort resulting in a transfer of right to object and distribution maintenance. Each of farming produces has marketing channel different between one and another. Product marketing channel can change and be different dependent on area condition, time, and technology advance (Soetriono et al, 2006).

Table 6 shows that 43 respondents $(50,0 \%)$ consider that organic rice product is marketed easily belonging to low category. Organic rice harvest output is usually sold in the form of dry grain to farmer group association and Appoli. Middleman (penebas) usually buys 
rice directly on the farm. Gapoktan (farmer group association) cannot receive organic rice bravely from the farmers in the local area and it only sells organic rice produced by group or leased from group's members the quality of which has been reliable. The group has not been able to maintain the quality of organic rice produced in the area because control mechanism is difficult to perform, thereby relying more on mutual trust between business performers. Marketing is performed by Appoli in cooperation with Sahabat Sejahtera Cooperaives. Sahabat Sejahtera Cooperatives is the one established by Appoli on November 27, 2013.

Table 6 - Distribution of Respondents by Marketing

\begin{tabular}{llllll}
\hline Marketing & Criteria & & Amount $(\mathrm{n})$ & Percentage $(\%)$ \\
\hline Marketing of Organic Rice Products & Low & $:$ & Consider & 43 & 50,0 \\
\cline { 2 - 5 } & Medium & $:$ & Doubtful & 7 & 8,1 \\
\cline { 2 - 5 } & High & $:$ & Agree & 36 & 41,9 \\
\hline Price of Organic Rice Products & Low & $:$ & Disagree & 37 & 43,0 \\
\cline { 2 - 5 } & Medium & $:$ & Doubtful & 10 & 11,6 \\
\cline { 2 - 5 } & High & $:$ & Agree & 39 & 45,3 \\
\hline Market Demand & Low & $:$ & Disagree & 2 & 2,3 \\
\cline { 2 - 5 } & Medium & $:$ & Doubtful & 69 & 80,2 \\
\cline { 2 - 5 } & High & $:$ & Agree & 15 & 17,4 \\
\hline
\end{tabular}

Source: Primary Data (Questionnaire), 2017.

The farmers sell unhulled rice to Appoli or farmer group in some stages, harvesting in the farm, taking unhulled rice to Appoli or gapoktan and weighing it. Dry unhulled rice deposited to cooperatives to be reprocessed in order to get high-quality organic rice. Organic rice types processed in this cooperative include red rice, IR 64 and pandan wangi. Organic rice is packaged in $1 \mathrm{~kg}, 5 \mathrm{~kg}$ and $25 \mathrm{~kg}$ sizes. Sahabat Sejahtera Cooperatives can absorb and market 292,5 tons Harvest Dry Unhulled Rice (Indonesian: Gabah Kering Panen or GKP) in one planting season. The processing stage conducted in this cooperative includes sunbathing, warehousing, milling, grading, sorting, blower, packing, and marketing. Mawarni (2008) suggests that some problems occurring in organic rice marketing are difficulty in getting certification, poor ability of maintaining market's trust, for example, by mixing other rice, and inability of maintaining organic farming product availability corresponding to market demand.

Organic rice price belongs to high category as well, according to 39 respondents $(45,3 \%)$. The price of organic rice is higher than that of conventional rice. The high price of organic rice can encourage the farmers to apply organic rice cultivation. The better and more stable price of organic rice will encourage the wider development of organic rice. The price of organic rice at farmer level is about IDR 15,000 - IDR 20,000, while the price of non-organic rice is about IDR 9,000.00 - IDR 12,000.00. Added-value the farmers obtain from organic rice development is about IDR 6,000.00 - IDR 8,000.00. The farmers have not yet enjoyed this added value because the farmer group as the main accommodator has not been ready to accept the farmers' product entirely due to limited capital, non-cash payment system, and the group's difficulty of controlling the quality of organic rice produced.

Market demand belongs to medium category, according to 69 respondents $(80,2 \%)$. Organic rice marketing has distinctive segment, upper-middle class of society. Appoli's organic rice marketing uses Arjuna brand, with production legality or Indonesian National Standard (Indonesian: Standar Nasional Indonesia or SNI) certification and organic rice nutrition content being included on the label. Farmer group finds difficulty in complying with production continuity because its production volume is still low and only relies on organic rice produced by reliable group or group members' lands.

The result of multiple linear regression analysis on the effect of marketing on organic rice cultivation sustainability is presented as follows:

Table 7 shows that coefficient of marketing channel on organic rice cultivation sustainability is 0,231 . T-statistic probability (Sign) value is 0,017 less than $\alpha$ of 0,05 . The result of decision does not support $\mathrm{H}_{0}$ but supports $\mathrm{H}_{\mathrm{a}}$ or in other words, marketing variable 
$(X)$ affects significantly the organic rice cultivation sustainability $(Y)$. It indicates that organic rice product marketing, organic rice product price, and market demand affect organic rice cultivation sustainability.

Table 7 - Test on the effect of marketing on organic rice sustainability

\begin{tabular}{lllll}
\hline Comment & $\beta$ & Sign & $\alpha$ & Decision \\
\hline Pyx & 0,231 & 0,017 & 0,05 & $\mathrm{H}_{0}$ is not supported and $\mathrm{H}_{\mathrm{a}}$ is supported \\
\hline
\end{tabular}

Source: Primary Data Analysis, 2017.

The farmers' ability of marketing organic rice can be implemented through a variety of distribution channels based on consumers' demand. Marketing can be said as successful when the farmers have market chance and distribution channel can be reached by farmers. In addition, the farmers can sell its product discretely with higher bargaining position. Organic rice harvest can be sold directly to the consumers at high price or corresponding to the farmers' price standard. The farmers can sell organic rice to Appoli or gapoktan in the form of wet or dry unhulled rice with higher price than non-organic rice. In conventional rice farming, the farmers can sell its product in local market in the form of rice or in rice mill and unhulled rice in the farm through middleman.

Some of organic rice products are intended to self-consumption, some others are sold in traditional market and still some others are sold directly to Appoli or deposited to farmer group. Appoli institution helps market its organic rice by means of establishing a mutually benefiting partnership between farmers and marketer. Appoli's marketer includes PT Bloom Agro Jakarta, UD Tama Jaya Yogyakarta, UD Rizky Subur Yogyakarta, PT BNS Jakarta and Koperasi Bina Bakat Surakarta. Appoli also has Sahabat Sejahtera Cooperatives as the attempt of guarantying the marketing of its members' products. Rice varieties usually produced by farmers are Pandan Wangi, black rice, red rice and Ciherang/IR 64 rice.

Neither Appoli nor farmer group accepts organic rice produced by the local farmers easily and they sell organic rice produced by lands owned or leased by farmers or members of group the quality of which has been reliable. Such the condition makes the volume of rice sold relatively limited, while the demand for rice produced by this group is very large. The group has not been able to serve as quality guarantor over organic rice produced by the local farmers because control mechanism is difficult to perform thereby relying more on the aspect of mutual trust between business performers. Institution and product standardization expected to deal with the problem of organic rice quality control, in fact, have not been utilized much by local farmers or farmer group. It is because of high cost of certification and farmers finding difficulty in administration affairs.

\section{CONCLUSION}

Considering the discussion above, it can be concluded that marketing affects significantly on organic rice cultivation sustainability. The government should facilitate both farmers and farmer groups' access to certification institution and make its cost lower, so that quality guaranty constituting one constraint with the marketing of organic rice can be overcome. The strategies taken in developing farming, among others, are to expand farmer or farmer group partnership, to expand marketer partnership and to improve promotion to potential consumers. The reinforcement of organic rice marketing institution should be supported by local government, quality overseeing institution and college.

\section{REFERENCES}

1. Aliansi Organis Indonesia. 2017. Statistik Pertanian Organik Indonesia 2017. Bogor.

2. BPS Kabupaten Boyolali. 2016. Produksi Padi dan Palawija Kabupaten Boyolali. Berita Resmi Statistik No. 1/08/3309/Th.I.

3. Effendi, S dan Tukiran. 2014. Metode Penelitian Survei. LP3ES. Jakarta. 
4. Kartasapoetra, A.G. 1987. Teknologi Penyuluhan Pertanian. Bumi Aksara. Jakarta.

5. Mardikanto, T. dan Sutarni, S. 1982. Pengantar Penyuluhan Pertanian dalam Teori dan Praktek. Hapsara. Surakarta.

6. Mardikanto, T. 1994. Bunga Rampai Pembangunan Pertanian. UNS Press. Surakarta.

7. Rogers, E.M. 1983. Diffusions of Innovations, Third Edition. Free Press. New York.

8. Rosenow, Soltysiak dan Verschuur. 1996. Organic Farming, Sustainable Agriculture Put Into Practice. IFOAM. Jerman.

9. Salikin, K. 2003. Sistem Pertanian Berkelanjutan. Kanisius. Yogyakarta.

10. Saptana dan Ashari. 2007. Pembangunan Pertanian Berkelanjutan Melalui Kemitraan Usaha. Litbang Pertanian Volume 26 No. 4: 123-130.

11. Saragih, B. 2001. Penyuluhan Pertanian. Yayasan Pengembangan Sinar Tani. Jakarta.

12. Simanhuluk. B, Purwoko. A, Apri. F. 2011. Adopsi Petani Terhadap Sistem Rice Intensification (SRI) di Desa Bukit Peninjauan I Kecamatan Sukaraja Kabupaten Seluma. Jurnal Agribis Volume IV No 2. Juli 2011. ISSN: 2086-7956.

13. Soetriono, Anik Suwandari dan Rijanto. 2006. Pengantar Ilmu Pertanian. Bayumedia Publishing. Malang.

14. Suprihono, B. 2003. Analisis Efisiensi Usaha Padi pada Lahan Sawah di Kecamatan Karanganyar Kabupaten Demak. Tesis. Magister Ilmu Ekonomi Studi Pembangunan. Fakultas Ekonomi. Universitas Diponegoro.

15. Suwarto. 2011. Kelembagaan Lahan dan Tenaga Kerja Pada Usahatani. UNS Press dan LPP UNS. Surakarta.

16. Wahyuni, S. 2000. Pemberdayaan Kelembagaan Masyarakat Tani Mendukung Percepatan Adopsi dan Keberlanjutan Adopsi Teknologi Usahatani Lahan Rawa. Sistem Usahatani Lahan Pasang Surut-ISDP. Badan Litbang Pertanian. Bogor. 